\title{
Evaluating Carbon Footprint Behavior in the Agriculture and Energy Sectors: A Review
}

\author{
Andrés López Astudillo Ph.D(c). / alopez@icesi.edu.co \\ Lina Marcela Rodríguez / Imrodriguez@icesi.edu.co \\ Claudia Marcela Lubo / cmlubo@icesi.edu.co \\ Fernando Arenas Ph.D(c). / faarenas@icesi.edu.co
}

Beatriz Eugenia Sierra / beatriz_sierraruiz@yahoo.es

Grupo de Investigación ICUBO, Departamento de Ingeniería Industrial, Universidad Icesi

\begin{abstract}
Since the pre-industrial era, emissions of greenhouse gases have increased by about $70 \%$, given anthropogenic activities. Thus, System Dynamics represents a fundamental tool that makes it possible to adopt a systemic-complex approach to the research process of modeling the behavior of these gases in different sectors. This paper presents a literature review about related case studies, mainly in the agriculture and energy sectors. By virtue of these models, it is feasible to identify alternative scenarios for a carbon footprint indicator in order to support strategic decision-making in secure environments at low risk, cost, and time. This review emphasizes the significance of modeling the carbon footprint behavior as a complex dynamic system mainly focused on the agriculture sector, which contributes $38.1 \%$ of greenhouse gas emissions to the atmosphere. Finally, it concludes with a future research project to deploy it in a sugarcane cropping system, one of the most important agro-industrial producers in Colombia.
\end{abstract}

KEYWORDS System dynamics, simulations, carbon footprint models, greenhouse gas emissions, agriculture sector, energy sector.

Comportamiento de la huella de carbono en los sectores de agricultura y energía, una revisión

RESUMEN Desde la era pre-industrial, la emisión de gases de efecto invernadero ha aumentado en alrededor de $70 \%$, debido a las actividades antropogénicas. La Dinámica de Sistemas representa una herramienta fundamental, que permite adoptar un enfoque sistémico - complejo en los procesos de investigación de modelación del comportamiento de los gases en diferentes sectores. Este artículo revisa varios casos de estudio, principalmente en los sectores de agricultura y energía. Gracias a estos modelos, es posible identificar escenarios alternativos del indicador «Huella de Carbono» con el propósito de soportar decisiones estratégicas en ambientes virtuales seguros, que representen bajos niveles de riesgo, costo y tiempo. Esta revisión hace énfasis en la importancia de modelar el comportamiento de la huella de carbono como un sistema dinámico complejo, específicamente enfocado en el sector de la agricultura, el cual contribuye con el $38,1 \%$ de las emisiones de gases de efecto invernadero hacia la atmósfera. Concluye con un trabajo futuro de investigación para la estimación del comportamiento de los gases de efecto invernadero en un sistema de cultivo de caña de azúcar, una de las mayores agroindustrias de Colombia

PALABRAS CLAVE Dinámica de Sistemas, simulaciones, modelos de Huella de Carbono, emisiones de Gases de Efecto Invernadero, sector de la Agricultura, sector de la Energía.
Comportamento da pegada de carbono dos setores agricultura e energia, uma revisão

RESUMO Desde a era pré-industrial, as emissões de gases de efeito estufa aumentaram em cerca de $70 \%$ devido às atividades antrópicas. A dinâmica de sistemas é uma ferramenta fundamental que permite uma abordagem sistêmica - complexo nos processos de investigação de modelação do comportamento dos gases em diferentes setores. Este artigo analisa vários estudos de caso, principalmente nos setores agricultura e energia. Graças a estes modelos é possível identificar cenários alternativos do indicador "Pegada de Carbono", com o objetivo de apoiar as decisões estratégicas em ambientes virtuais seguros que representem baixos níveis de risco, custo e tempo. Esta revisão destaca a importância de modelar o comportamento da pegada de carbono como um sistema dinâmico, complexo, focado especificamente na agricultura, setor que responde por $38,1 \%$ das emissões de gases de efeito estufa na atmosfera. Conclui-se com futuras pesquisas para estimar o comportamento de gases de efeito estufa em um sistema de cultura de cana-de-açúcar, uma das maiores agroindústrias na Colômbia.

PALAVRAS-CHAVE Dinâmica de Sistemas, simulações, modelos de pegada de Carbono, emissões de gases de efeito estufa, setor da Agricultura, sector da Energia. 


\section{Introduction}

Around the world, in regard to environmental issues, many organizations have built social-economic, transport, ecological, environmental management models, among others. These are based on static (Alkafoury, Bady, Aly, \& Negm, 2013), mathematical (Peter, Hartmann, \& Hediger2006; Klier et al., 2011), optimal (Thorburn, Biggs, Collins, \& Probert, 2010), empirical and mechanistic (Schils, Olesen, Del Prado, \& Soussana, 2007), and numerical (Hediger, 2006) languages. Nevertheless, when researching the complexity of the accumulation of greenhouse gas [GHG] emissions and their further contribution to climate change, modeling from the system dynamics [SD] perspective becomes a useful tool to design an abstract and simple representation of a real system, and to identify the critical points of GHG emissions mitigation and reduction with the aim of obtaining sustainable improvement opportunities. Thus, this review presents different worldwide cases studying carbon footprint $[\mathrm{CF}]$ dynamic modeling in the agriculture and energy sectors, which represent the main sources of GHG emissions around the world. Some of these models were built up with Vensim ${ }^{\circledR}$ and Stella ${ }^{\circledR}$ software, which provides a user-friendly interface to visualize complex systems and to analyze simulation scenarios (ISEE Systems, 2006).

As part of this literature review, it is necessary to give special attention to the importance of modeling $\mathrm{CF}$ behavior for agriculture sector, which is considered the largest source of emissions in Colombia. Hence, a future research project is proposed to assess carbon dioxide $\left(\mathrm{CO}_{2}\right)$ and nitrous oxide $\left(\mathrm{N}_{2} \mathrm{O}\right)$ emissions from two specific sources, namely the fossil fuel and fertilizer used in the sugarcane cropping system, which represents the most important agro-industrial production in Colombia, where the main producer is the state of Valle del Cauca.

As per the modeling process proposed by Sterman (2000) as mentioned in Section 3, and the different CF models produced for each case study presented, this research project is structured in four phases. The first stage, the research phase, involves developing a literature review on standards of $\mathrm{CF}$ estimations and models in different sectors, considering SD. It evaluates the behavior of GHG emissions mainly in the agriculture sector. The second stage, the dynamic modeling design phase, considers the structural features (components and relationships) and functional features (equations and parameters)

\section{Introducción}

Alrededor del mundo, algunas organizaciones han construido modelos socio-económicos, ecológicos, medio-ambientales, entre otros, basados en lenguajes estáticos (Alkafoury, Bady, Aly, \& Negm, 2013), matemáticos (Peter, 2006) y (Klier, 2011), óptimos (Thorburn, Biggs, Collins, \& Probert, 2010), empíricos y mecánicos (Schils, Olesen, Del Prado, \& Soussana, 2007), y numéricos (Hediger, 2006). Sin embargo, en el proceso de investigación realizado sobre la complejidad en la acumulación de las emisiones de Gases de Efecto Invernadero [GEI] y su futura contribución al cambio climático, la modelación a partir de la perspectiva de la Dinámica de Sistemas [DS] se convierte en una herramienta útil para diseñar una representación abstracta y simple del sistema real, y para identificar los puntos críticos de mitigación y/o reducción de las emisiones de GEI, con el fin de identificar oportunidades de mejora sostenibles en el tiempo. En general, esta revisión presenta diferentes casos de estudio alrededor del mundo sobre modelación dinámica de la Huella de Carbono [HC] en los sectores de agricultura y energía, los cuales representan las principales fuentes de emisión de GEI alrededor del mundo. Algunos de estos modelos fueron construidos utilizando los software Vensim ${ }^{\circledR}$ y Stella ${ }^{\circledR}$, los cuales proveen una interfaz de usuario amigable para visualizar los sistemas complejos y analizar los escenarios de simulación (System, 2006).

Esta revisión presta atención especial a la importancia de modelar el comportamiento de la $\mathrm{HC}$ en el sector de la agricultura, considerado la mayor fuente de emisiones en Colombia. A partir de esto, se propone un proyecto de investigación futuro para evaluar las emisiones de Dióxido de Carbono $\left(\mathrm{CO}_{2}\right)$ y Óxido Nitroso $\left(\mathrm{N}_{2} \mathrm{O}\right)$, resultantes de dos fuentes de emisión específicas, como son la combustión fósil y el uso de fertilizantes, a partir de un sistema de cultivo de caña de azúcar, que corresponde, no solo a la mayor agroindustria de Colombia, sino a la actividad en la que el Valle del Cauca es líder en el país.

De acuerdo, tanto con el proceso de modelación propuesto por Sterman (2000), como con los diferentes modelos de huella de carbono del producto para cada caso de estudio presentado, este proyecto de investigación se estructuró en cuatro fases: la primera, denominada «Fase de Investigación», involucra el desarrollo de la presente revisión literaria sobre modelos de estimación del comportamiento dinámico de la HC en diferentes sectores, principalmente en el sector agricultor; la segunda, llamada «Fase de Diseño de la Modelación Dinámica», considera las características estructurales (componentes y relaciones) y las características funcionales (ecuaciones y parámetros) del modelo dado; la tercera, denominada «Fase de Prueba y Validación», permite evaluar si el modelo provee una representación adecuada del sistema real; y la cuarta, la «Fase de Análisis de Resultados y Simulación», incluye la simulación de escenarios para validar los modelos simulados por los datos teóricos calculados por medio de las directrices del Panel Intergubernamental del Cambio Climático [IPCG] y los datos reales obtenidos en los trabajos de campo.

Con el objetivo de cubrir la primera etapa del proyecto de in- 
vestigación mencionado, la presente revisión presenta el estado actual de los modelos dinámicos de emisión de GEI alrededor del mundo, asociados con las prácticas antropogénicas llevadas a cabo en los sectores de la agricultura y energía.

\section{Comportamiento de las emisiones de GEI por sectores}

Desde la era pre-industrial, las concentraciones atmosféricas de GEI se han incrementado significativamente como consecuencia de las actividades humanas basadas en el uso de combustibles fósiles y del cambio constante en el uso de la tierra (IPCG, 2012). De acuerdo con el IPCG, a través del siglo XX la temperatura promedio se ha incrementado en $0.7^{\circ} \mathrm{C}$ sobre la superficie de la tierra, y para finales del siglo XXI habrá un aumento de la temperatura en un rango entre $1.4^{\circ} \mathrm{C}$ y $5.8^{\circ} \mathrm{C}$, por tanto, un incremento del nivel del mar desde $0.09 \mathrm{~m}$ hasta $0.88 \mathrm{~m}$, como consecuencia de los intensos fenómenos climáticos-El Niño y La Niña-. Los investigadores han estimado para el año 2100, una concentración de las emisiones de $\mathrm{CO}_{2}$ entre 540 ppm y 970 ppm, en contraste con las emisiones aproximadas de 280 ppm emitidos en la era pre-industrial, y cerca de 368 ppm emitidos en el año 2000.

De acuerdo con la metáfora hidrodinámica tradicional, Senge (1995) propuso considerar la atmósfera terrestre como una bañera gigante, como se muestra en la Figura 1. El volumen total de los gases acumulados es considerado como el inventario que representa la diferencia entre el flujo de entradayel flujo de salida. Estos flujos hacen referencia a las emisiones de GEI hacia la atmósfera y su absorción por parte de los sumideros naturales (océanos, árboles, etc.), respectivamente. Como consecuencia del calentamiento global, cuando el flujo viscoso (gas) se calienta, su nivel de viscosidad se incrementa, lo que hace que los océanos se calienten y los flujos corran lentamente en esta bañera representativa de la situación real, lo cual indica un impacto negativo sobre la estabilidad del clima (Villarreal, 2011). Los legisladores internacionales han desarrollado iniciativas para medir, controlar, y reducir las emisiones de GEI por medio de la creación de modelos que describen la huella de carbono durante el ciclo de vida de los productos y servicios de una organización, para alcanzar sostenibilidad ambiental, económica y política.

El medio ambiente es un sistema de gran complejidad dinámica, compuesto por múltiples agentes, entre los cuales se encuentran los factores no controlables (clima, temperatura, presión, y humedad), las mediciones irrepetibles y la multidisciplinariedad de escenarios. Dado lo anterior, es necesario adoptar un enfoque sistémico complejo de los impactos medio ambientales y analizar su comportamiento a través del uso de modelos estratégicos, particularmente de modelos causales y de inventario y flujo, conocidos como modelos de Forrester (Sterman, 2002). A través de un pensamiento sinérgico y comprensible, es posible establecer las relaciones determinísticas de causa-efecto entre las variables controlables y las no controlables, provenientes de fuentes de emisión directas e indirectas. Esto permite identificar y priorizar los puntos críticos que rep- of the given model. Then the third phase, testing and validation, is devoted to validating whether the model provides an accurate representation of the real system. This validation is performed on the structure and level of system behavior. Finally, the simulations and results analysis phase includes simulation scenarios to validate models powered by the theoretical data given by IPCC guideline estimations and real data obtained from field work.

For the purpose of covering the first stage of the proposed research project, the present literature review aims to offer a current state of dynamic models worldwide of the GHG emissions associated with anthropogenic activities from the agricultural and energy sectors.

\section{Greenhouse gas emissions be- havior by sectors}

Since the pre-industrial era, atmospheric concentrations of greenhouse gases have increased significantly on account of human activities generally based on the use of fossil fuels and constant land use change (Gitay, Suárez, Watson, \& Dokken, 2012). According to the Intergovernmental Panel on Climate Change, throughout the twentieth century there has been an average increase in temperature of $0.7^{\circ} \mathrm{C}$ on the land surface. The IPCG has estimated that by the end of the twenty-first century there will be a temperature rise in the range of $1.4^{\circ} \mathrm{C}$ to $5.8^{\circ} \mathrm{C}$, and therefore a sea level increase of from $0.09 \mathrm{~m}$ to $0.88 \mathrm{~m}$, alongside related intense climate phenomena such as El Niño and La Niña. Researchers have estimated that by 2100 there will be a concentration of $\mathrm{CO}_{2}$ in the range of 540 to $970 \mathrm{ppm}$, in contrast to approximately $280 \mathrm{ppm}$ emitted in the pre-industrial era, and close to $368 \mathrm{ppm}$ in the year 2000.

In accordance with the typical hydrodynamic metaphor, Senge (1995) proposes to consider our atmosphere as a giant bathtub, as Figure 1 illustrates. The total volume of gases it holds accumulated is considered as stock, which is the difference between input flow and output flow. These terms refer to GHG emissions to the atmosphere and GHG absorption due to natural sinks (oceans, forest, etc.), respectively. As consequence of global warming, when the viscous fluid (gas) becomes warmer its viscosity increases, the ocean heats up and the flow runs more slowly out of this real-life bathtub. This current situation is having an impact on the stability of our climate (Villarreal, 2011). International policymakers have devel- 
oped initiatives for measuring, controlling and reducing GHG emissions by creating models to describe the $\mathrm{CF}$ throughout the life cycles of products and services, allowing any organization to achieve environmental, economic and political sustainability.

The environment is a complex dynamic system, composed of multiple agents, such as non-controllable factors (clima-

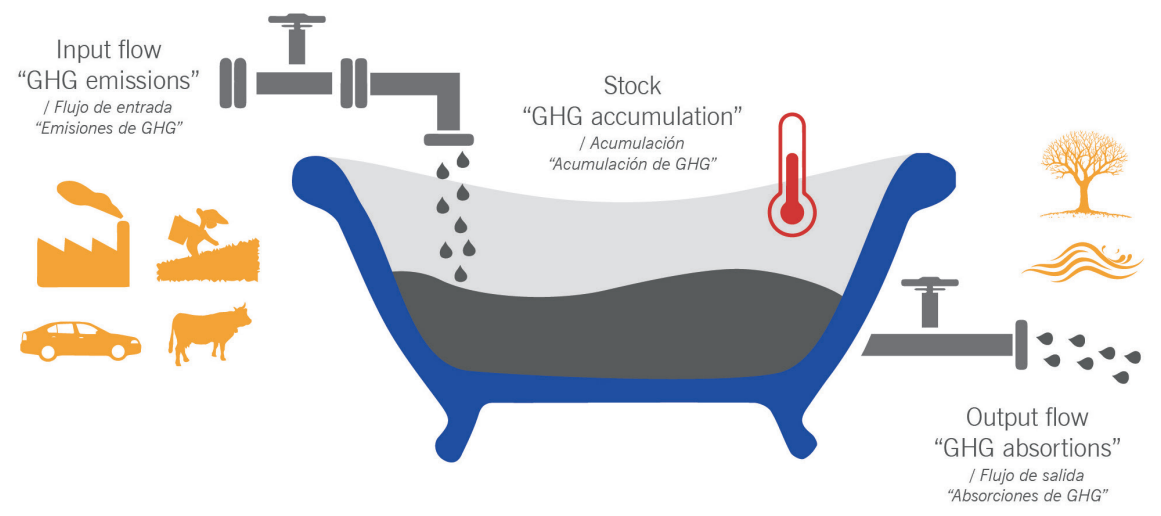

Figure 1. Bathtub diagram to illustrate GHG emissions accumulation into atmosphere / Ilustración de la acumulación en las emisiones de GEI en la atmósfera (Sterman, 2002) te, temperature, pressure, and humidity), unrepeatable measurements, and multidisciplinary scenarios. Thus, it is necessary to adopt a complex systemic approach to environmental impacts and analyze its behavior through the use of strategic models, particularly the Causal model and the Stock and Flow model, known as the Forrester model in SD theory (Sterman, 2002). Following comprehensive and synergic thinking, it is possible to establish a deterministic cause-effect relation between controllable and non-controllable variables coming from direct and indirect emission sources in order to identify and prioritize critical points that allow mitigation strategies to be determined.

In the Second National Communication of Colombia to the United Nations Framework Convention on Climate Change [UNFCGC] held in Costa Rica in 2009, the national GHG inventory belonging to Colombia by2000 and 2004 years was presented. The results represent significant contributions of GHG emissions by sector, composed as follows: $50 \%$ from carbon dioxide $\left(\mathrm{CO}_{2}\right), 30 \%$ from methane $\left(\mathrm{CH}_{4}\right), 19 \%$ from nitrous oxide $\left(\mathrm{N}_{2} \mathrm{O}\right)$, and the remaining $1 \%$, corresponding to the remaining $\mathrm{GHG}$, which are not in the Montreal Protocol, such as HFGs, CFGs, halocarbons and $\mathrm{SF}_{6}$ (IDEAM, 2009).

The five sectors responsible for Colombian GHG emissions are agriculture, energy, land use change and silviculture, waste management, and industrial processes, as shown below (see FIGURE 2). It is interesting to observe that $40 \%$ of these sectors generate $74.70 \%$ of total emissions, namely agriculture and energy. resentan una oportunidad de mejora para desarrollar estrategias sostenibles de mitigación de GEI.

En la segunda comunicación nacional de Colombia para la Convención Marco de la Naciones Unidas sobre el Cambio Climático [CMNUCG] sostenida en 2009 en Costa Rica, se presentó el inventario nacional de GEI de Colombia, para el periodo 2000 a 2004. Los resultados presentan una contribución significativa de las emisiones de GEI por sectores, distribuido de la siguiente forma: $50 \%$ de dióxido de carbono $\left(\mathrm{CO}_{2}\right), 30 \%$ de metano $\left(\mathrm{CH}_{4}\right), 19 \%$ de óxido nitroso $\left(\mathrm{N}_{2} \mathrm{O}\right)$, y el $1 \%$ restante, de gases no considerados por el «Protocolo de Montreal», como son los HFCs, CFCs, halocarbonos y $\mathrm{SF}_{6}$ (IDEAM, 2009).

Existen cinco sectores de emisión de GEI en Colombia: agricultura, energía, cambio en el uso de la tierra y silvicultura, gestión de residuos, y procesos industriales, como se presenta

\section{GHG emissions produced by sector in Colombia (2014) / Emisiones GHG producidas por sector en Colombia (2014)}

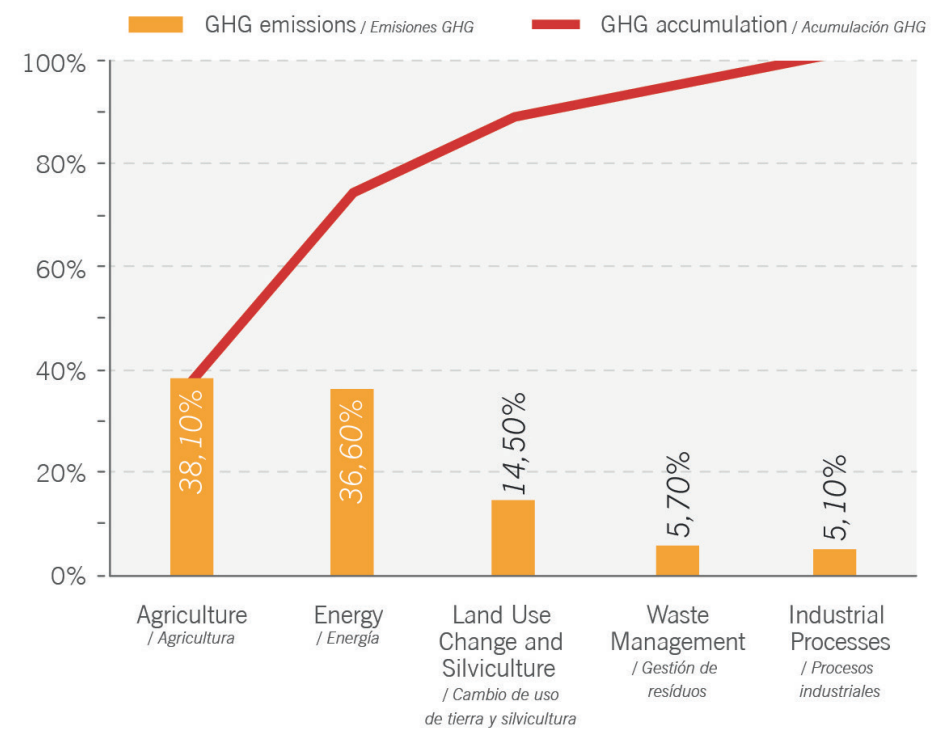

Figure 2. Total GHG emissions and participation by sectors- Colombia, 2004 / Emisiones totales de GEl y participación por sectores- Colombia, 2004 (IDEAM, 2009) 
en la Figura 2. Es interesante observar que $40 \%$ de los sectores genera el $74.70 \%$ de las emisiones, los cuales pertenecen a los sectores de agricultura y energía.

La economía colombiana está principalmente basada en la agricultura. El sector contribuye con el 9\% del Producto Nacional Bruto [PNB]. Dentro de los cultivos, la caña de azúcar representa la mayor producción agro-industrial, con un 23\% (SAC, 2012); a su vez, la mayor producción del país se concentra en el Valle del Cauca, que cuenta con 223.905 hectáreas plantadas (Asocaña, s.f.). La agricultura, como un aspecto destacado, representa la mayor fuente de emisión de GEI (38.10\%), debido a la fermentación entérica, con $18.48 \%$, así como a los suelos agrícolas, con $18.11 \%$ del total de las emisiones del sector (IDEAM, 2009). Desafortunadamente, no se encuentra información sobre las emisiones de GEI generadas durante la preparación de los cultivos de caña de azúcar en Colombia.

\section{Teoría sobre modelación de los sistemas dinámicos y simulación}

Una de las características más importantes de la modelación del comportamiento de la HC es la funcionalidad de la dinámica de sistemas como herramienta para abstraer diferentes escenarios del sistema real y lograr una mejor comprensión del mismo. La modelación permite identificar los puntos críticos de mitigación de las emisiones de GEI, así como tomar decisiones efectivas para la implementación de oportunidades de mejora sostenibles.

Es necesario considerar el Pensamiento Sistémico [PS] como la base fundamental de la modelación. Según Martínez y Londoño (2013), el PS es una herramienta metodológica útil para resolver problemas y remover paradigmas mentales. Los tres principios del PS son: la articulación del problema, el análisis de sistemas y el uso de modelos de diferentes herramientas de ingeniería, como los diagramas causales y los análisis de sensibilidad.

Sterman (2000) presenta las cinco etapas de la modelación dinámica como un proceso de retroalimentación o ciclo iterativo que es afectado principalmente por los modelos mentales y por la información recolectada desde el mundo real, la cual es puesta a prueba, de forma virtual, a través del modelo. El proceso presentado fue construido con el objetivo de diseñar nuevas estrategias, estructuras y reglas de decisión para direccionar una problemática compleja. De esta forma, es posible crear e implementar políticas, adquirir nuevo conocimiento para evaluar una situación y considerar futuras mejoras.

Los modelos de simulación están enfocados en un mejor entendimiento de los impactos tecnológicos, económicos y medioambientales. Estos modelos se encuentran clasificados en dos grupos: empíricos y mecánicos. Los modelos empíricos son descriptivos, es decir, sólo permiten observar la información sin análisis alguno sobre los procesos fisiológicos, mientras que los modelos mecánicos son capaces de explicar, por ejemplo, la fisiología del cultivo, considerando factores como la temperatura, el índice de área foliar y la fotosíntesis, entre otros (Hernández, Soto, \& Caballero, 2009). Por otro lado, es necesario considerar la diferencia entre los modelos estáticos
Colombia is a country whose economy is largely based on agriculture. This sector contributes $9 \%$ of the national Gross Domestic Product [GDP]. Among the crops, sugarcane represents the most important agro-industrial production with 23\% (SAC, 2012), of which the main producer is the state of Valle del Cauca, with 223.905 hectares planted (Asocaña, s.f.). This underlines that the agriculture sector represents the major GHG emission source $(38.10 \%)$ due to enteric fermentation, with a contribution of $18.48 \%$, as well as agricultural soils, which contribute $18.11 \%$ of the total emissions by this specific sector (IDEAM, 2009). Unfortunately, there is no information about sugarcane crops in the data on Colombian GHG emissions.

\section{System dynamics modeling and simulations theory}

One of the most striking features of modeling the $\mathrm{CF}$ behavior is the usefulness of system dynamics [SD], a tool to abstract different scenarios of a real system, and its capacity to obtain a better system comprehension. Modeling allows us to identify the critical points of GHG emissions mitigation and reduction, and to make effective decisions for the implementation of sustainable improvement opportunities.

It is necessary to consider systemic thinking [ST] as a fundamental basis for modeling systems. Based on Martinez, ST is a methodological tool to solve problems and to eliminate mental paradigms. There are three principles of ST: problem articulation, systems analysis and the use of models by different engineering tools, such as causal loop diagrams, complexity and sensitivity analysis.

Sterman (2000) presents five steps of dynamic modeling as a loop feedback process or iterative cycle that is affected mainly by mental models and information collected from the real world, which is later tested virtually through the model. The process performed is built up with the aim of designing new strategies, structures, and decisions rules to address complex problems. Likewise, it enables us to create and to implement policies that will lead to new insights to evaluate a situation and to consider further improvements.

Simulation models are used for a better understanding of technological, economic, and environmental impacts. These models are classified in two groups: empirical and mechanistic. Empirical models are descriptive, since 
they only observe data, without any analysis of physiological processes. The mechanistic models are capable of explaining, for example, crop physiology, by means of considering factors such as temperature, the index leaf area, and photosynthesis, among others (Hernández, Soto, \& Caballero, 2009) . Also, they are categorized into static and dynamic models. The first one includes relations among parameters, while the second one describes a temporal evolution for each variable, for example, in the agriculture sector, simulations of the photosynthesis process coming from a static model, although the $\mathrm{CF}$ balance is considered a dynamic model. This review presents a holistic approach to understanding dynamic models from different perspectives.

\section{GHG emissions causal loop diagram}

In an effort to determine cause and effect

relations among the GHG emissions gene-

rated by the main contributor sectors of these atmospheric concentrations, namely agriculture and energy, a causal loop diagram was elaborated based on the system thinking structure (Sterman, 2002). It is valuable to observe five feedback loops, which represent an increase of GHG emissions resulting from these sectors, and longterm collateral effects that will have a negative impact on both environmental and socio-economic development.

According to the phases of the dynamic modeling process (see Figure 3) and the research problem, it is necessary to elaborate the dynamic hypothesis in terms of feedbacks and the stock and flow structure of the system. Next the causal loop diagram (FIgURE 4) is composed by the dynamic hypothesis related to each other, as described below.

Starting with the hypothesis that countries currently have a scarcity of natural resources, and thus socio-economic backwardness, both the energy and agriculture sectors must look to improve the living conditions of their inhabitants. Nonetheless, in the energy sector the increasing growth of industries and residential sectors is related with high-level demand for fossil fuel consumption. Fossil energy is a concentrated solar energy with carbon compounds. When carbon is burnt, it produces

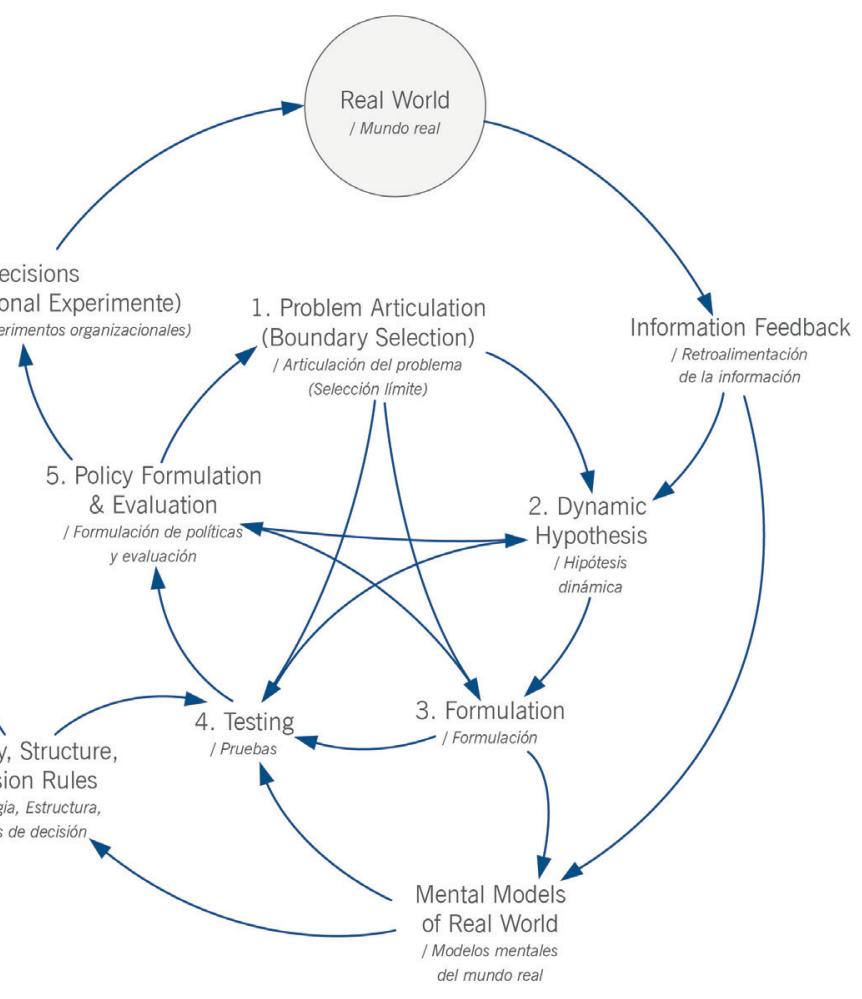
2000)

y dinámicos. Los primeros incluyen las relaciones existentes entre los parámetros, mientras que los segundos describen la evolución temporal de cada variable en consideración. Por ejemplo, en el sector de la agricultura las simulaciones sobre los procesos fotosintéticos provienen de un modelo estático, sin embargo, el balance de HC generado durante la preparación de los cultivos, requiere de un modelo dinámico. Esta revisión presenta un enfoque holístico que permite una comprensión global de los modelos dinámicos desde diferentes perspectivas.

\section{Diagramas causales de las emisiones de GEI}

En un esfuerzo por determinar las relaciones de causa y efecto existente entre las emisiones de GEI generadas por los principales sectores responsables de las concentraciones atmosféricas de estos gases, principalmente los de agricultura y energía, se desarrolló un diagrama causal basado en la estructura de pensamiento sistémico (Sterman, 2002). Es factible observar cinco ciclos de retroalimentación, los cuales representan un incremento en las emisiones de GEI provenientes de estos sectores y los efectos colaterales en el largo plazo, los cuales tienen un impacto negativo en el desarrollo ambiental y socioeconómico.

De acuerdo con las fases del Proceso de Modelación Dinámico (Figura 3) y el problema de investigación, es necesario elaborar hipótesis dinámicas en términos de retroalimentaciones y de acuerdo con la estructura de inventarios y flujos del sistema. Por tanto, el diagrama causal que se presenta en la Figura 4 está compuesto por hipótesis dinámicas, las cuales se describen 


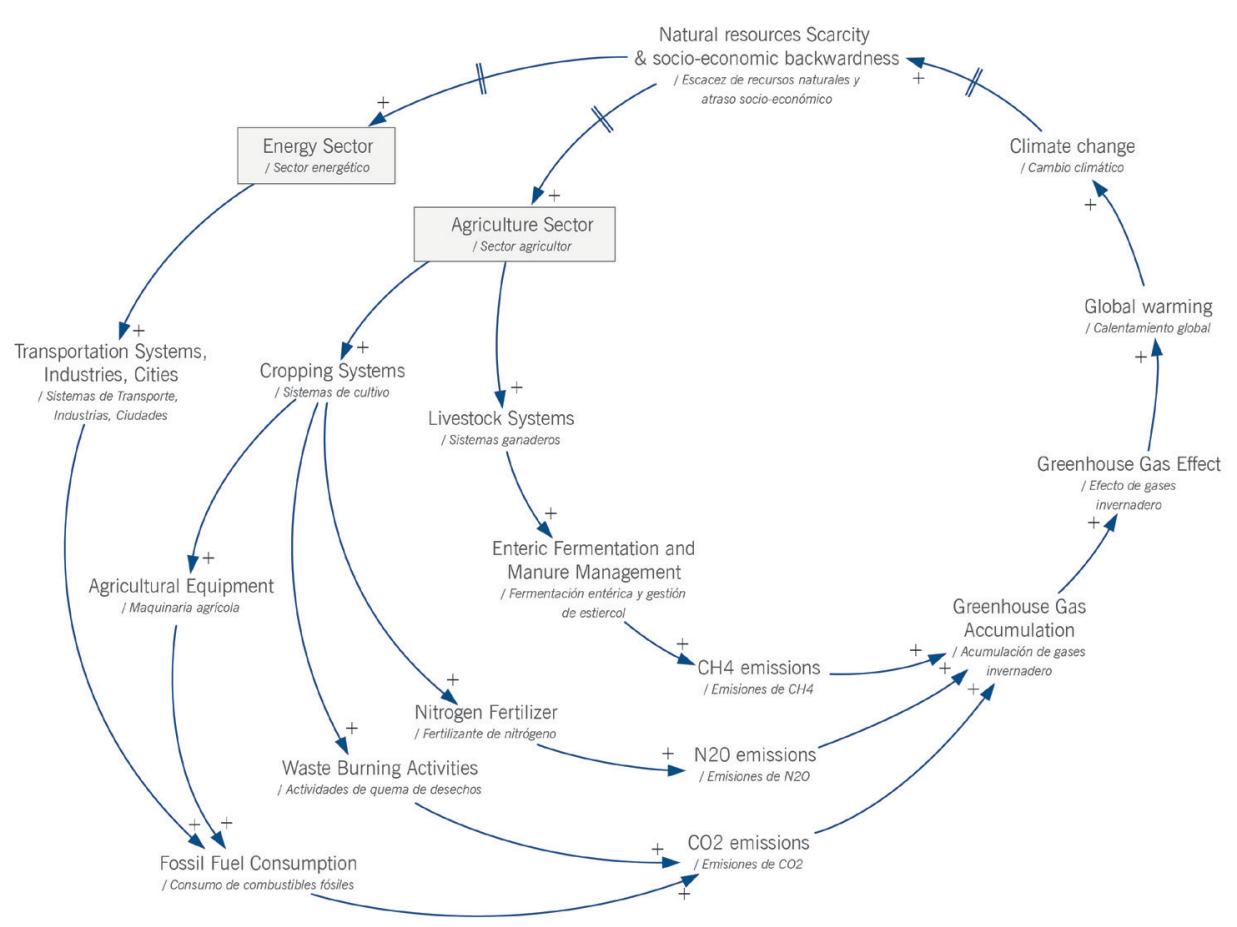

Figure 4. Causal loop diagram of GHG emissions by agriculture and energy sectors / Diagrama de ciclo causal de las emisiones de GEI provenientes de los sector de agricultura y energía

$\mathrm{CO}_{2}$ particles that extend through the whole atmosphere. Now, with the initial objective of obtaining high levels of food production, in the agriculture sector the anthropogenic activities from livestock systems are increasing enteric fermentation and manure management, which both cause high rates of $\mathrm{CH}_{4}$ emissions. Similarly, management practices in cropping systems increase the usage of nitrogen fertilization, which is the main factor responsible for a significant increase of $\mathrm{N}_{2} \mathrm{O}$ emissions. The principal GHG emissions $\mathrm{CO}_{2}$,

a continuación, iniciando con aquella que dice que los países actualmente poseen escasez de recursos naturales, lo cual se ve reflejado en su atraso socio-económico; ambos sectores agricultura y energía deben enfocarse en la búsqueda de mejores condiciones de vida para sus habitantes. Sin embargo, en el sector de la energía el crecimiento acelerado de las industrias y los sectores residenciales está relacionado directamente con una mayor demanda de consumo de combustible fósil. Es necesario mencionar que la energía fósil es energía solar concentrada, más componentes de carbono. Cuando el carbono se quema, se generan partículas de $\mathrm{CO}_{2}$, las cuales se esparcen a través de toda la atmósfera. Adicionalmente, con el propósito inicial de obtener altos niveles de producción de alimentos, en el sector de la agricultura específicamente en los sistemas de ganado, las actividades antropogénicas incrementan la fermentación entérica y la administración del estiércol, lo cual causa altos niveles de emisiones de $\mathrm{CH}_{4}$. De manera similar, las prácticas de gestión en los sistemas de cultivo fortalecen el uso de la fertilización nitrogenada, la principal responsable del incremento en las emisiones de $\mathrm{N}_{2} \mathrm{O}$.

En cuanto a las principales emisiones de GEI $\left(\mathrm{CO}_{2}, \mathrm{CH}_{4}\right.$, $\mathrm{N}_{2} \mathrm{O}$ ), éstas se acumulan en la atmósfera acelerando el proceso natural de los GEI sobre el tiempo, lo cual conlleva al calentamiento global del planeta y, por tanto, a su cambio climático. Finalmente, el cambio climático ocasionará impactos negativos en los recursos naturales, necesarios para el desarrollo socio-económico de los países. Esta situación genera escasez e interrumpe el desarrollo socio-económico de las naciones.
$\mathrm{CH}_{4}, \mathrm{~N}_{2} \mathrm{O}$ )are accumulated in the atmosphere, accelerating the natural process of the greenhouse gas effect over time, which increases the planet's global warming and leads to global climate change. Finally, climate change will have negative impacts on the natural resources on which the socio-economic development of countries depends, generating a scarcity of natural resources and socio-economic backwardness.

\section{Current GHG emissions models by sector}

In order to present a review of current GHG emissions dynamic models, several worldwide cases of study were classified in accordance with these main contributor sectors, not only in Colombia but also in developing countries Japan, China, United States, Australia and Brazil), as shown below.

\subsection{Agriculture sector}

According to the results of the last Colombian national GHG inventory in 2004, the agriculture sector is the biggest source of emissions, contributing about 38.1\% of total national emissions (see Figure 2). This literature review includes both livestock and farming systems. Their contribution to the concentration of GHG is mainly caused by enteric fermentation, solid waste from animals, agricultural soils, and burning of agricultural 
wastes. Ruminant livestock systems contribute to global warming through emissions of methane, stemming from solid waste from ruminant animals. In Colombia, the most important sources of livestock emission are from the cattle, pig and poultry sectors. Hence, livestock systems contribute $93.19 \%$ of the $\mathrm{CH}_{4}$ emissions in the agriculture sector (IDEAM, 2009) . On the other hand, according to IDEAM (2009), intensive farming practices represent one of the principal environmental impacts chiefly in the form of $\mathrm{N}_{2} \mathrm{O}$ emissions, owing to the frequent use of chemicals, such as fertilizers and pesticides; these represent $95.6 \%$ of the $\mathrm{N}_{2} \mathrm{O}$ emissions resulting from the agriculture sector. Note that factors like burning of agricultural wastes and fossil fuel use are not considered in several studies, as they are not the main source of emissions from this specific sector.

Given the increasing level of vulnerability to global environmental changes and the necessity to reduce GHG emissions in the agriculture sector, several dynamic models have been developed in soils and crops with the aim of proposing strategies for maintaining soil fertility and a higher food production, while ensuring a minimal level of GHG emissions. The following case studies enable us to illustrate the dynamic complexity of these gases and their behavior through long periods of simulation.

\subsubsection{Livestock systems}

In the first place, in livestock systems one study describes some current whole-farm GHG models and their potential applications. DairyWise is an empirical model that integrates the main sub-systems of a dairy farm, and it is used for technical, environmental and financial simulations of dairy farms. According to IPCG guidelines, GHG emissions were calculated with refined emission factors for three categories of ground water level and for two soil types (mineral and organic) (Schils et al., 2007) . Farm $G H G$ is another model of carbon $(\mathrm{C})$ and nitrogen (N) flows on dairy farms designed to allow the quantification of direct and indirect $\mathrm{CH}_{4}$ and $\mathrm{N}_{2} \mathrm{O}$ emissions from dairy farms and to elaborate mitigation measures and strategies. This emission model includes the use of energy, fertilizers, pesticides and feedstuffs (Olesen et al., 2006). Needless to say, the emissions estimations that feed the model are based on IPGG methodology Tier 1 and Tier 2 (Houghton, 1997) and IPCG Good Practice Guidance (Penman, 2000). Otherwise, at the farm level a sustainable and integrated management system for dairy production, known as the $S I M S_{D A I R Y}$ modeling frame-

\section{Modelo de las emisiones actuales de GEI por sectores}

Con el fin de presentar una revisión de los modelos dinámicos de emisiones de GEI, algunos casos de estudio alrededor del mundo fueron clasificados de acuerdo con los sectores de mayor contribución a la emisión de GEI, no sólo en Colombia sino también en países desarrollados, como Japón, China, Estados Unidos, Australia y Brasil, como se describe a continuación.

\subsection{Sector agrícola}

Según los resultados del último inventario nacional de GEI de Colombia, obtenido en 2004, este sector está clasificado como la mayor fuente de emisiones, con un aporte aproximado de $38,1 \%$ de las emisiones nacionales totales (ver Figura 2). Esta revisión incluye, tanto los sistemas de ganadería, como los de cultivo. Su contribución a la concentración de los GEI es causada principalmente por la fermentación entérica, los residuos sólidos de los animales, los suelos agrícolas y la quema de residuos agrícolas.

Los sistemas ganaderos de rumiantes contribuyen al calentamiento global a través de las emisiones de metano, derivado de los residuos sólidos de los animales rumiantes. En Colombia, las fuentes de emisión de ganado más importantes están compuestas por el ganado, vacuno y porcino, y por la avicultura. Los sistemas ganaderos contribuyen con 93.19\% de las emisiones de $\mathrm{CH}_{4}$ en el sector de la agricultura (IDEAM, 2009). Por otro lado, las prácticas de agricultura intensiva aportan el $95.6 \%$ de las emisiones de $\mathrm{N}_{2} \mathrm{O}$, debido al uso de productos químicos, como fertilizantes y pesticidas, entre otros. Es necesario tener en cuenta que factores como la quema de residuos agrícolas y el uso de combustibles fósiles no son considerados en los estudios investigados, dado que no representan una fuente principal de las emisiones aportadas por este sector específico.

Dado el creciente nivel de vulnerabilidad para enfrentar los cambios globales medio ambientales, y ante la necesidad de reducir las emisiones de GEI en el sector de la agricultura, se han desarrollado varios modelos dinámicos con el fin de proponer estrategias para mantener la fertilidad de los suelos, con una mayor producción de alimentos y un nivel mínimo de emisiones de GEI. Los siguientes casos de estudio permiten ilustrar la complejidad dinámica de estos gases y su comportamiento a través de largos períodos de simulación.

\subsubsection{Sistemas de ganadería}

En primer lugar, se encontró un estudio que describe algunos modelos actuales de GEI y sus posibles aplicaciones. «DairyWise» es un modelo empírico que integra los principales sub-sistemas de las granjas, y es utilizado para simulaciones técnicas, ambientales y financieras de las explotaciones lecheras. Según los lineamientos del IPCG, las emisiones de GEI fueron calculadas con los factores de emisión específicos para tres categorías de nivel de agua subterránea y dos tipos de suelo-minerales y orgánicos- 
(Schils et al., 2007). «FarmGHG»es otro modelo que evalúa los flujos de carbono $(\mathrm{C})$ y nitrógeno $(\mathrm{N})$, cuantifica las emisiones de $\mathrm{CH}_{4}$ y $\mathrm{N}_{2} \mathrm{O}$-directas e indirectas- generadas en las granjas lecheras y elabora medidas y estrategias de mitigación. Este modelo de emisión incluye el uso de energía, fertilizantes, pesticidas y madurantes (Olesen et al., 2006). Vale la pena mencionar que el cálculo de las emisiones que alimentaron el modelo se basó en la metodología de cálculo Nivel 1 y Nivel 2 del IPCG (Houghton, 1997) y en la «Guía de Buenas Prácticas» del IPGG (Penman, 2000). Por otro lado, un estudio sobre sistemas de gestión sostenibles e integrados para la producción lechera, conocido como estructura de modelación «SIMS $\mathrm{SAIRY}_{\text {", fue elaborado para }}$ simular características como biodiversidad, calidad del producto, calidad del suelo y bienestar de los animales (Del Prado et al., 2006). En el caso del estudio evaluado sobre el modelo «FarmGHG», se incluyen solo las emisiones de $\mathrm{N}_{2} \mathrm{O}$ y $\mathrm{CH}_{4}$. Las emisiones de $\mathrm{N}_{2} \mathrm{O}$ provenientes de los suelos gestionados son modeladas considerando los procesos de nitrificación y desnitrificación del suelo (Brown, Scholefield, Jewkes, \& Lockyer, 2003). Adicionalmente, las pérdidas de $\mathrm{CH}_{4}$ fueron simuladas de acuerdo con los estudios conducidos por Giger-Reverdin, Morand-Fehr, y Tran (2003). Como resultado de ello, un análisis de sensibilidad para el modelo de simulación «SIMS $\mathrm{SAIRY}_{\text {", }}$ comprende las condiciones edafo-climáticas y los parámetros de gestión agrícola que afectan a las emisiones de GEI. «FarmSim» es otro modelo de emisión de GEI; incluye un modelo de simulación de los pastizales, llamado «PaSim» (Riedo, Grub, Rosset, \& Fuhrer, 1998) y las estimaciones basadas en la metodología de cálculo Nivel 1 y Nivel 2 del IPGC (Houghton, 1997) para determinar las emisiones de $\mathrm{CH}_{4}$ y $\mathrm{N}_{2} \mathrm{O}$ provenientes de las tierras de cultivo y la ganadería.

De la misma forma, las comunidades de Investigación en Taiwán han desarrollado estudios sobre modelación de las emisiones de GEI procedentes de la gestión de residuos sólidos desechados por los animales en el campo, haciendo uso del software Stella (Horng, Lee, \& Liao, 2004). A pesar de que las investigaciones en arrozales fueron las más representativas, algunos modelos dinámicos se desarrollaron en sistemas ganaderos y campos de vegetación. Asimismo, se planearon estrategias y se elaboraron herramientas de control estratégico.

\subsubsection{Sistemas de cultivo}

Con respecto de los sistemas de cultivo, (Stöckle et al., 2012) se evaluó comportamiento de GEI durante la preparación de tres suelos secos y uno irrigado, según el tipo de labranza (convencional, reducida y cero). Este estudio utilizó «CropSyst», un modelo de simulación de sistemas de cultivo múltiple que ha sido usado en el Pacífico Noroccidental de EE.UU. (Pannkuk, Stöckle, \& Papendick, 1998), y otros lugares del mundo (Wang et al., 2006). Sus resultados demuestran que el tipo de labranza reducida representa una de las estrategias actuales para mitigar las emisiones de GEI, y que la conversión de una labranza convencional work was elaborated to simulate farm sustainability attributes (biodiversity, landscape, product quality, soil quality and animal welfare) (Del Prado et al., 2006). As in the Farm $G H G$ model, this case includes only $\mathrm{N}_{2} \mathrm{O}$ and $\mathrm{CH}_{4}$ emissions. Thus, $\mathrm{N}_{2} \mathrm{O}$ emissions from soil are modeled considering denitrification and nitrification processes (Brown, Scholefield, Jewkes, \& Lockyer, 2003). Besides, $\mathrm{CH}_{4}$ losses are simulated according to studies conducted by Giger-Reverdin, Morand-Fehr, \& Tran (2003). As a result, a sensitivity analysis of SIMS $_{D A I R Y}$ comprises edapho-climatic conditions and farm management parameters that affect GHG emissions. FarmSim is another GHG emissions model, which includes a pasture simulation model, called PaSim (Riedo, Grub, Rosset, \& Fuhrer, 1998) and estimations based on IPCG methodology Tier 1 and Tier 2 (Houghton, 1997) for $\mathrm{CH}_{4}$ and $\mathrm{N}_{2} \mathrm{O}$ emissions from croplands and cattle housing.

In the same way, research communities in Taiwan have conducted studies for modeling GHG emissions coming from animal farming solid wastes, through the STELLA system dynamics model (Horng, Lee, \&Liao, 2004). Although researches on paddy fields were the most representative, many dynamic models were developed in animal farming, waste from animal farming, fruit, and vegetation fields, in return for planning strategies and elaborating strategic policy control tools.

\subsubsection{Cropping systems}

Regarding cropping systems, Stöckle et al. (2012) evaluated the GHG effects of conventional, reduced, and no tillage at one irrigated and three dry land locations, using a multiyear, multicrop, and daily time step cropping systems simulation model, called CropSyst. This model has been used in the US Pacific Northwest (Pannkuk, Stöckle, \& Papendick, 1998), and many other world locations (Wang \& McGlinchy, 2009). The results of this study indicate that reduced tillage is one current strategy to mitigate GHG emissions. Also, the conversion of conventional tillage to reduced tillage produced higher carbon sequestration in soils.

Del Grosso et al. (2009) emphasized the importance of promoting simulation models to visualize $\mathrm{N}_{2} \mathrm{O}$ emissions behavior, by including factors such as soil organic matter, soil water, management of nitrogen applications, as well as environmental influences on the soil and plants. To illustrate the latter, an ecosystem model was developed to estimate direct and indirect $\mathrm{N}_{2} \mathrm{O}$ emissions for major cropping systems in the USA, known as Daycent (Del 
Grosso, Mosier, Parton, \& Ojima, 2005). It is based on the emission factor [EF] methodology used by the IPCC. However, this model accounts for factors such as soil type, climate, and tillage intensity that are disregarded by the IPCC. It was simulated under conventional tillage and non-tillage cropping systems. The results suggest that conversion to non-tillage at the national scale could reduce US agricultural emissions by approximately $20 \%$.

Considering the above, another instance is presented in Quzhou County, Hebei province in northern China, where researchers tested a process-based model called the Denitrification-Decomposition [DNDC] model for predicting $\mathrm{CO}_{2}$ and $\mathrm{N}_{2} \mathrm{O}$ emissions in three management scenarios. These scenarios are no-till, increased crop residue incorporation, and reduced fertilizer application rate, from a winter wheat-maize rotation field, which is a common cropping system across the Chinese agricultural regions (Li et al., 2010). Several 50-year scenarios were simulated to predict the long-term impacts on crop yield. The results of this study indicate how environmental and management factors affect the GHG emissions level. For instance, $\mathrm{CO}_{2}$ emissions are related to temperature, the quantities and quality of soil organic carbon [SOC], and the tillage method. Similarly, $\mathrm{N}_{2} \mathrm{O}$ emissions are affected by high temperatures, initial SOC, and total fertilizer nitrogen input. The model suggests that the incorporation of manure or crop-residue instead of intensive fertilizer application could help to significantly mitigate GHG emissions from the tested agro-ecosystem.

Given the complexity of some models so as to include environmental impacts, crop growth, and yield loss, Aggarwal, Kalra, Chander, \& Pathak (2005) conducted a modeling study that integrated the effects of variety, pests, soil, weather, and management practices on crop yields, water, nitrogen, carbon dynamics, and GHG emissions in both aerobic and anaerobic conditions. In particular, they developed a generic crop model known as InfoCrop. Especially, it considers the influence of climate, followed by soil factors, crop growth, crop-pest interactions, the effects of water deficit, flooding, and organic carbon dynamics, among others. An investigative study presents an Info Crop model performed on rice and wheat crops, including the location of treatments, seasons, varieties, nitrogen management, organic matter, irrigation, and multiple pest incidences (Aggarwal, Kalra, Chander, \& Pathak, 2006). This model was written in Fortran Simulation Translator programming language, a otra, reducida, produce mayor secuestro de carbono en los suelos.

Del Grosso et al., (2009) enfatizaron en la importancia de promover modelos de simulación para visualizar el comportamiento de las emisiones de $\mathrm{N}_{2} \mathrm{O}$, incluyendo factores como la materia orgánica y el agua del suelo, la administración en las aplicaciones de nitrógeno y las influencias ambientales sobre el suelo y las plantas. Para ilustrar lo anterior, se desarrolló un modelo eco-sistémico para estimar las emisiones directas e indirectas de $\mathrm{N}_{2} \mathrm{O}$ en los principales sistemas de cultivo de EE.UU. Estos modelos son conocidos como «Daycent» (Del Grosso, Mosier, Parton, \& Ojima, 2005). De acuerdo con lo anterior, los modelos se basan en los Factores de Emisión [EF] considerados por los lineamientos del IPGC. Sin embargo, este tipo de modelo tuvo en cuenta factores como el tipo de suelo, el clima, y la intensidad de labranza, todos ellos ignorados por el IPCC. Es necesario mencionar que en este estudio se realizaron simulaciones bajo sistemas de cultivo sin labranza y con labranza convencional. Los escenarios obtenidos sugieren que la conversión a la no-labranza en la escala nacional podría reducir aproximadamente un 20\% las emisiones agrícolas de los Estados Unidos.

En otro caso de estudio del condado de Quzhou en la provincia Hebei ubicada en el Norte de China, los investigadores probaron un modelo de desnitrificación-descomposición [DNDC] para predecir las emisiones de $\mathrm{CO}_{2} \mathrm{y} \mathrm{N}_{2} \mathrm{O}$, en tres escenarios de gestión. Estos escenarios incluyen suelos sin labranza, aumento de la incorporación de residuos de cosecha, y reducción de la tasa de aplicación de fertilizantes de un campo de rotación trigo-maíz en invierno-un sistema de cultivo común en China-(Li et al., 2010). Algunos escenarios se simularon a 50 años para predecir el impacto ambiental en el largo plazo sobre el rendimiento del cultivo. Los resultados de este estudio indican cómo los factores ambientales y de manejo afectan el nivel de emisión de GEI. Por ejemplo, las emisiones de $\mathrm{CO}_{2}$ se ven afectadas por la temperatura, la cantidad y calidad de carbono orgánico del suelo [SOC] y el método de labranza. Del mismo modo, las emisiones de $\mathrm{N}_{2} \mathrm{O}$ se ven afectadas por los altos niveles de temperatura, el SOC inicial y la entrada total de fertilizante nitrogenado. El modelo sugiere que la incorporación de estiércol o de residuos de cultivos, en lugar de la aplicación intensiva de fertilizantes, podría ayudar a mitigar las emisiones de GEI de forma significativa de este agro-ecosistema evaluado.

Dada la complejidad de algunos modelos para incluir el impacto ambiental, el crecimiento del cultivo y las pérdidas de rendimiento, Aggarwal, Kalra, Chander, y Pathak (2005) condujeron un estudio de modelación que integra los efectos de la variedad de la planta, las plagas, el suelo, el clima y las prácticas de gestión, para el rendimiento de los cultivos, el agua, el nitrógeno, la dinámica del carbono y las emisiones de GEI, tanto en condiciones aeróbicas, como anaeróbicas. Los autores desarrollaron un modelo de 
cultivo genérico conocido como «InfoCrop», el cual consideró, especialmente, la influencia del clima, seguido de los factores: suelo, crecimiento de los cultivos, interacción cultivo-plagas, efectos de déficit de agua, inundaciones y dinámica del carbono orgánico, entre otros. Por ejemplo, un estudio de investigación presenta un modelo «InfoCrop» realizado en los cultivos de arroz y trigo, incluyendo tratamientos de localización, estaciones, variedades, manejo de nitrógeno, materia orgánica, irrigación, y múltiples incidencias de plagas (Aggarwal, Kalra, Chander, \& Pathak, 2006). Este modelo fue escrito en Fortran, el lenguaje de programación de simulación sugerido por el Consorcio Internacional para la Aplicación de Sistemas Agrícolas [ICASA] como el estándar para la simulación de sistemas (Jones, Keating, \& Porter, 2001). En general, «InfoCrop» es una plataforma integrada diseñada para crear estrategias para minimizar la emisión de GEI y asegurar la fertilidad del suelo, al tiempo que se aumenta la producción de alimentos en el largo plazo.

Finalmente, es importante mencionar la investigación desarrollada en el cultivo de la caña de azúcar, uno de los más importantes en los países tropicales y subtropicales (Denmead et al., 2010), cultivo que además, es considerado uno de los mayores contribuyentes a las emisiones $\operatorname{deN}_{2} \mathrm{O}$, como consecuencia de las altas tasas de aplicación de fertilizante nitrogenado (FAO, 2006). El estudio fue desarrollado para estimar las emisiones de $\mathrm{N}_{2} \mathrm{O}$ provenientes de los sistemas de producción de caña de azúcar de Australia, utilizando el modelo «Simulador de Sistemas de Producción Agrícolas [APSIM]» (Thorburn et al., 2010), modelo que permite simular procesos biofísicos en los sistemas agrícolas, relacionados con los resultados económicos y ecológicos de las prácticas de gestión. Está estructurado por módulos de gestión de suelo y plantas (Keating et al., 2003). Un modelo de cultivo de caña de azúcar se desplegó en el marco APSIM para simular el ciclo del nitrógeno del suelo-cultivo (Keating, Robertson, Muchow, \& Huth, 1999) y un sub-modelo de desnitrificación en el modelo APSIM- Suelo N (Probert, Dimes, Keating, Dalal, \& Strong, 1998). Thorburn et al., (2010) agregaron algoritmos para calcular las tasas de $\mathrm{N}_{2}$ / $\mathrm{N}_{2} \mathrm{O}$ durante el proceso de desnitrificación, y para predecir las emisiones de $\mathrm{N}_{2} \mathrm{O}$ provenientes del proceso de nitrificación, con el objetivo de simular estas emisiones en un largo plazo (40 a 60 años). Los resultados presentan altas tasas de emisión de $\mathrm{N}_{2} \mathrm{O}$ con respecto, tanto al nivel de $\mathrm{N}$ esperado por el uso de fertilizantes, como a la experiencia en otros cultivos, dadas las interacciones entre los diferentes factores que intervienen en el campo (suelo y clima) y administración (fertilizante nitrogenado, residuo de cultivo, irrigación).

\subsection{Sector Energía}

Es el responsable del $36.6 \%$ de las emisiones totales nacionales, particularmente de las de $\mathrm{CO}_{2}$ (ver Figura 2), como consecuencia de la combustión de aceite, combustible y gas natural. En cuanto a los sub-sectores, en 2004 el sub-sector as recommended by the International Consortium for Agricultural Systems Applications [ICASA] as a standard language for systems simulation (Jones, Keating, \& Porter, 2001). Overall, InfoCrop is an integrated platform designed to create strategies for minimizing GHG emissions and ensuring soil fertility, while increasing food production in the long term.

Finally, it is important not to overlook a research study developed on sugarcane cropping, which is an important crop in tropical and sub-tropical countries (Denmead et al., 2010) and is one of the largest contributors of $\mathrm{N}_{2} \mathrm{O}$ emissions, given high rates of nitrogen $(\mathrm{N})$ fertilizer application (FAO, 2006). In particular, this study was developed to estimate $\mathrm{N}_{2} \mathrm{O}$ emissions in Australian sugarcane production systems, using the Agricultural Systems Production Systems Simulator [APSIM] model (Thorburn et al., 2010). The APSIM model enables us to simulate biophysical processes in agriculture systems, related with the economic and ecological outcomes of management practices. It is structured with plant, soil, and management modules (Keating et al., 2003). A sugarcane crop model was deployed in the APSIM framework to simulate soil-crop nitrogen cycling (Keating, Robertson, Muchow, \& Huth, 1999) and a denitrification sub-model in the APSIM-SoilN model (Probert, Dimes, Keating, Dalal, \& Strong, 1998). Thorburn et al. (2010) added algorithms to calculate $\mathrm{N}_{2} / \mathrm{N}_{2} \mathrm{O}$ ratios during denitrification, and then to predict $\mathrm{N}_{2} \mathrm{O}$ emissions from nitrification, with the objective of simulating these emissions over the long term, from 40 to 60 years. The results present higher rates of $\mathrm{N}_{2} \mathrm{O}$ emissions than expected for the level of $\mathrm{N}$ fertilizer use and compared with experience in other crops, given interactions among various site (soil and climate) and management (nitrogen fertilizer, crop residue, irrigation) factors.

\subsection{Energy sector}

The energy sector is responsible for $36.6 \%$ of total national emissions, particularly $\mathrm{CO}_{2}$ emissions (see Figure 2 ), as consequence of oil, fuel, and natural gas combustion. Concerning the sub-sectors, in 2004 transportation emitted $31.2 \%$, i.e., $21.769 \mathrm{Gg}_{\mathrm{CO}_{2}}$-eq by fossil fuel burning, $15.281 \mathrm{Gg} \mathrm{CO}_{2}$-eq by energy transformation centers, $13.098 \mathrm{Gg} \mathrm{CO}_{2}$-eq by the industrial sub-sector, and $6.062 \mathrm{Gg} \mathrm{CO}_{2}$-eq by other sub-sectors such as commercial and institutional, residential, agriculture, and fishing and forestry (IDEAM, 2009). In order to reduce the main GHG emissions, dynamic models have been applied around the world, with policy evaluations on the 
electricity industry (Ford, 1983) and (Naill, 1992), electricity supply, resources and pollution (Qudrat-Ullah, 2005), and energy efficiency analysis and management (Dyner, Smith, \& Peña, 1995).

\subsubsection{Economic systems}

In an effort to analyze the economic impacts of energy and environmental policy, many researchers have extended the Dynamic Computable General Equilibrium [CGE] models, most of all in Japan and China. For instance, Matsumoto (2011) examined the economic and environmental effects of climate change mitigation in Japan, under different simulation time horizons. This study showed a proportional relationship between economic growth and $\mathrm{CO}_{2}$ emission reduction in the short term, and economic damage in the long term. Likewise, Zhang (1998) analyzed the macroeconomic effects of China's $\mathrm{CO}_{2}$ emissions by applying a $C G E$ model of the Chinese economy. Another important study based on the $C G E$ model investigates the variation characteristics of China's economy, energy consumption and carbon emissions from 2007 to 2030, and the impacts on China's economic growth, energy consumption, and carbon emissions under the carbon tax policy scenarios (Chi, Guo, Zheng, \& Zhang, 2014).

\subsubsection{Transportation systems}

In accordance with the International Energy Agency, the transportation system is the biggest source of energy consumption and carbon emissions, contributing 13.5\% of worldwide global warming (Baumert, Herzog, \& Pershing, 2005). Chiefly, road transport is responsible for $75 \%$ of GHG emissions in this sector (Regmi, 2012). Several dynamic emissions models have been developed for road transportation. These are classified in two categories, namely traffic situation models and instantaneous models. The first considers the effect of traffic dynamics on the aggregated link level and different road types. Examples include the HBEFA and ARTEMIS models (Joumard et al., 2007). Otherwise, instantaneous models provide emissions rates for vehicle operation over short time periods, including the PHEM and MOVES models (Wang \& McGlinchy, 2009). Another case of models of emissions is illustrated by Del Grosso et al. (2009), whose study developed the Gladyste [Global Scale System Dynamic Simulation Model for Transport Emissions] model, with the intention of estimating transport demand and emissions and simulating the impacts of policy and technological criteria in transport-related sectors. de transporte generó el 31.2\% de las emisiones de GEI-es decir, 21.769 $\mathrm{Gg} \mathrm{CO}_{2}$-eq, por la quema de combustibles fósiles; 15.281 $\mathrm{Gg} \mathrm{CO}_{2}$-eq, por el centro de transformación de energía; $13.098 \mathrm{Gg} \mathrm{CO}_{2}$-eq, por el sub-sector industrial; y $6.062 \mathrm{Gg} \mathrm{CO}_{2}$-eq, por otros sub-sectores, como el comercial e institucional, el residencial, el agrícola y el de pesca y silvicultura (IDEAM, 2009). Con el propósito de reducir las principales emisiones de GEI, alrededor del mundo se han desarrollado modelos dinámicos y una posterior evaluación de políticas en la industria eléctrica (Ford, 1983) y (Naill, 1992) en los suministros de electricidad, recursos y contaminación (Qudrat-Ullah, 2005), y en la gestión y análisis de la eficiencia energética (Dyner, Smith, \& Peña, 1995).

\subsubsection{Sistemas económicos}

En un intento por analizar el impacto económico de las políticas energéticas y ambientales, muchos investigadores ampliaron los modelos de Equilibrio General Dinámico [EGD], que se concentran en Japón y China. Matsumoto (2011), por ejemplo, examinó los efectos económicos y ambientales de la mitigación del cambio climático en Japón, bajo diferentes horizontes de tiempo de simulación. Su estudio mostró una relación proporcional entre el crecimiento económico y la reducción de las emisiones de $\mathrm{CO}_{2}$ en un corto periodo de tiempo, e impacto económico a largo plazo. Igualmente Zhang (1998) analizó los efectos macroeconómicos de las emisiones de $\mathrm{CO}_{2}$ en China aplicando el modelo EGD de la economía China. Otro estudio importante tomó como base a las características de la variación del modelo investigativo EGD de la economía China, y tuvo en cuenta el consumo energético y las emisiones de carbono desde 2007 hasta 2030, los impactos en el crecimiento económico de China, y las emisiones de carbono bajo la política de escenarios, considerando los impuestos del carbono (Chi, Guo, Zheng, \& Zhang, 2014).

\subsubsection{Sistemas de transporte}

De acuerdo con la Agencia Internacional de la Energía, los sistemas de transporte son los mayores consumidores de energía y una gran fuente de emisiones de carbono-contribuyen con el $13.5 \%$ del calentamiento global del planeta (Baumert, Herzog, \& Pershing, 2005).

El transporte por carretera es responsable del $75 \%$ de las emisiones de GEI en este sector (REGMI, 2012). Varios modelos dinámicos han sido desarrollados en este sub-sector. Ellos se clasifican en dos categorías: modelos de situación de tráfico y modelos instantáneos. El primero considera el efecto de la dinámica del tráfico en el nivel de vínculo agregado y los diferentes tipos de vías. Algunos ejemplos hacen referencia a los modelos de HBEFA y ARTEMIS (Joumard et al., 2007). Por su parte, los modelos instantáneos proporcionan tasas de emisiones para el funcionamiento de los vehículos en cortos periodos de tiempo, como es el caso de los modelos PHEM y MOVES (Wang \& McGlinchy, 2009). Otro caso de modelos de emisión de GEI es ilustrado por Del Grosso et al., (2005), quienes desarrollaron el modelo de simulación de dinámica de sistemas a 
escala global de las emisiones del transporte (GLADTSTE), con la intención de estimar la demanda de transporte y las emisiones, y simular los impactos de tipo político y tecnológico en los sectores relacionados con el transporte.

Dada esta situación, Lei, Zhang, y Li (2012) elaboraron un modelo de DS para el sistema de transporte de una ciudad baja en carbono y la conservación de la energía, realizado en Shanghái (China). El estudio presenta la relación dinámica entre la economía urbana, la población urbana, los vehículos urbanos la infraestructura de transporte urbano, y la emisión de carbono en el transporte urbano. Los resultados sugieren reforzar el manejo de la demanda de transporte urbano y realizar mejoras en su estructura para así reducir los niveles de carbono y por lo tanto apuntar al logro de una ciudad ecológica.

\subsubsection{Sistemas industriales}

La manufactura es una de las principales causas del calentamiento global, debido a que la producción demanda altos niveles de consumo energético. Esta investigación examinó la forma de minimizar la HC del producto, controlando, al mismo tiempo, los costos de manufactura durante el diseño de los productos y la planeación de la producción (Trappey, Trappey, Hsiao, Ou, \& Chang, 2012). De acuerdo con este objetivo, se llevó a cabo una simulación, empleando el modelado de DS, para identificar la rentabilidad de la HC durante el rediseño de un producto ambiental. Los datos de entrada incluyen materias primas, etapas de producción y transporte de la cadena de suministro, mientras que los de salida, los costos de controlar y reducir la HC. En consecuencia, los resultados que muestra esta fase de materiales, representan un punto crítico a considerar para reducir la HC. En un caso de estudio presentado sobre la fabricación de un proyector, se evaluaron varios escenarios con el propósito de justificar un método costo efectivo o rentable para reducir las emisiones de GEI y recolectar datos para planeaciones estratégicas y futuras investigaciones.

Desde la perspectiva de la industria del papel - la tercera mayor consumidora de la energía industrial en EE.UU, y la segunda mayor producción en los EE.UU y China, Newell y Vos (2011) condujeron un estudio comparativo de las emisiones de $\mathrm{CO}_{2}$ generadas desde el papel estucado de las industrias de estos dos países y elaboraron un modelo para evaluar la HC de un producto, como resultado de la variación geográfica y el cambio en el uso de la tierra; a través de la extracción de madera, el transporte, y las etapas de producción de pulpa y de los procesos usados en su transformación, con el fin de obtener un inventario real de los GEI que alcanzan los resultados obtenidos por el IPCG. Se consideró una pérdida de carbono por parte del cultivo de madera.

Por otra parte, Wang, Wu, Huo, y Liu (2008) complementaron el modelo de gases de efecto invernadero, emisiones reguladas y uso de energía en transporte [GREET] desarrollado por el Laboratorio Nacional Argonne, incluyendo el uso de energía y las emisiones de GEI del etanol pro-
Given that situation, Lei, Zhang, \& Li (2012) elaborated a SD model for an urban low-carbon transport system and energy conservation, which was simulated in the city of Shanghai, China. This study presents the dynamic relationships among the urban economy, urban population, urban vehicles, urban transportation infrastructure, and urban transportation carbon emissions. The result suggests reinforcing urban transport demand management and making urban transport structure improvements in order to achieve a low-carbon eco-city.

\subsubsection{Industrial systems}

Manufacturing is one of the main causes of global warming, due to production's demand for high energy consumption. One study examined a pathway to minimize the product carbon footprint, at the same time as controlling its manufacturing cost during collaborative product design and production planning (Trappey, Trappey, Hsiao, Ou, \& Chang, 2012). According to this objective, SD modeling was employed, whereby a simulation was carried out to identify cost-effective of the $\mathrm{CF}$ during a green product redesign. Input data included the raw materials, production and transportation stages of the supply chain, while output data included the costs of controlling and reducing the CF. Thus, the results demonstrate that the material stage is a critical point when considering reduction of the carbon footprint. In a case study on a projector manufacturer, several scenarios were evaluated with the purpose of justifying a cost-effective method to reduce GHG emissions and collect data for strategic planning and future research.

From the perspective of the paper industry, which is the third largest consumer of industrial energy in the United States, and represents the second highest level of production in the United States and China, Newell \& Vos (2011) conducted a comparative study of the $\mathrm{CO}_{2}$ emissions generated from the Chinese and US industries' coated paper production. Consequently, they elaborated a model for assessing the $\mathrm{CF}$ of the product as a result of geographic variation and land use change; through timber harvest, transportation, and pulp and production phases of the production process. With the aim of obtaining a real GHG inventory that rescales the results obtained by the IPCC, carbon loss from the timber harvest was considered.

On the other hand, based on the Greenhouse Gases, Regulated Emissions, and Energy Use in Transportation (GREET) model developed by Argonne National Laboratory, 
Wang expanded the model to include the energy use and GHG emissions of Brazilian-grown sugarcane ethanol. This last factor considers fertilizer production, sugarcane farming, sugarcane transportation, and sugarcane ethanol production in Brazil, ethanol transportation to ports and refueling stations, and the use of ethanol in vehicles. In addition, they examined various sensitivity cases to test uncertainties related to key input parameters. The results showed that the five main contributors to GHG emissions are open-field burning, $\mathrm{N}_{2} \mathrm{O}$ emissions from sugarcane fields, fertilizer production, sugarcane mill operation, and sugarcane farming.

\subsubsection{Integrated systems}

In the city of Beijing, a SD modeling of energy consumption and $\mathrm{CO}_{2}$ emissions was developed for the period 2005-2030, using STELLA software (Feng, Chen, \& Zhang, 2013). This framework is a compound of socioeconomic, agricultural, industrial, service, residential, and transport sub-models. The simulation results show that the service sector will probably replace the industrial sector with respect to energy consumption, assigning it a second place, followed by the transportation sector. Overall, cities are complex dynamic systems, composed of a variety of factors, such as economic development, population growth and migration, climate change, and consumer behavioral patterns. For that reason, it is necessary to consider a simulation model with a sensitivity analysis to evaluate the influences of these variables on energy consumption and the carbon emissions produced by these anthropogenic activities. Because traditional energy models were developed using deterministic forecasts of energy system evolution, this research adopted SD to describe the dynamic and stochastic behavior involved in urban development. This research focused on the city of Beijing to design an integrated SD model, simulating trends of energy demand and $\mathrm{CO}_{2}$ emissions from 2005 to 2030 in an effort to shape future energy planning, create guidelines for policy-making and provide suggestions for urban energy conservation and carbon emission reduction.

\section{Discussion and conclusions}

Around the world, most organizations have designed ecological, hydro-geological, atmospheric, and agricultural models using analog, mathematical, and numerical languages. However, these models are unable to analyze non-linear relationships among the variables involved in a complex system. As a consequence, it is necessary to con- ducido en los cultivos de caña de azúcar de Brasil. Este último factor considera la producción de fertilizantes, el cultivo y transporte de la caña de azúcar la producción del etanol y su transporte a los puertos y a las estaciones de reabastecimiento, y su uso en los vehículos. Además, se han examinado varios casos de sensibilidad para probar incertidumbres relacionadas con los parámetros de entrada. Los resultados muestran que los cinco principales contribuyentes a las emisiones de GEI son las quemas a campo abierto, las emisiones de $_{2} \mathrm{O}$ de los campos de la caña de azúcar, la producción de fertilizantes, los procesos de preparación del cultivo de la caña de azúcar y los procesos de producción del azúcar como producto terminado.

\subsubsection{Sistemas integrados}

En Beijing se desarrolló un modelo de DS acerca del consumo energético y las emisiones de $\mathrm{CO}_{2}$ durante el periodo 2005-2030, usando el software Stella (Feng, Chen, \& Zhang, 2013), cuyo marco de trabajo está compuesto por sub-modelos socioeconómicos, agricultores, industriales, de servicios, residenciales y de transporte. La simulación de resultados demostró que el sector servicios probablemente reemplazará al sector industrial con respecto al consumo energético, asignándole un segundo lugar, seguido del sector de transporte. En gran parte, las ciudades son complejos sistemas dinámicos, compuestos por una variedad de factores, tales como el desarrollo económico, el crecimiento poblacional y migratorio, el cambio climático, y los patrones comportamentales del consumidor, razón por la cual es necesario considerar un modelo de simulación con un análisis de sensibilidad que permita evaluar las influencias de estas variables en el consumo energético y en las emisiones de carbono producidas por estas actividades antropogénicas. Debido a que los modelos tradicionales de energía fueron desarrollados usando pronósticos determinados sobre la evolución de sistemas energéticos, esta investigación implementó la herramienta DS para describir la dinámica y el comportamiento estocástico involucrado en el desarrollo urbano. A partir de lo anterior, el estudio se enfocó en Beijing para diseñar un modelo integrado de DS, simulando las tendencias de la demanda energética y de las emisiones de $\mathrm{CO}_{2}$ desde 2005 hasta2030, en un esfuerzo por desarrollar futuras planeaciones energéticas y lineamientos para la elaboración de políticas y propuestas para la conservación de la energía urbana, en pro de la reducción de las emisiones de carbono.

\section{Discusión y conclusiones}

Alrededor del mundo, la mayoría de organizaciones ha diseñado modelos ecológicos, hidrogeológicos, atmosféricos, y agrícolas, usando lenguajes analógicos, matemáticos, y numéricos. Sin embargo, estos modelos son incapaces de analizar relaciones no lineales entre variables involucradas en un sistema complejo, por lo cual es necesario considerar herramientas de DS, para superar ese desafío y ayudar así a las organizaciones en la toma de decisiones efectivas. 
Tal como ha sido revisado, los modelos de DS son útiles para analizar los impactos socioeconómicos y las estrategias costo-efectivas de mitigación, los niveles de mantenimiento de la producción y la fertilidad del suelo. Esta revisión se enfocó en estudios investigativos de los sectores de energía y agrícola, quienes son los principales generadores de $\mathrm{CO}_{2}$ (transporte, sistemas productivos, servicios, sub-sectores residenciales), $\mathrm{CH}_{4}$ (sistemas de ganadería), y emisiones de $\mathrm{N}_{2} \mathrm{O}$ (sistemas de cultivo).

Con respecto al sector energético, esta revisión muestra algunos casos de estudio sobre efectos ambientales producidos por sistemas económicos, de transportes, industriales e integrados de ciudades, desarrollados en Japón, China, Estados Unidos, y Brasil. En cambio, en el sector agrícola, específicamente en los sistemas de ganado, fueron descritos algunos modelos completos actuales, principalmente de emisiones de $\mathrm{CH}_{4}$ que son el resultado de desperdicios sólidos del ganado, con aplicaciones en fincas lecheras de países desarrollados. Asimismo, en sistemas de cultivo, fueron analizados los comportamientos de las emisiones en diferentes tipos de labranza (convencional, reducida y sin labrar), específicamente en los cultivos de arroz, trigo, maíz y caña de azúcar en los suelos tropicales de China, Estados Unidos y Australia. En cuanto a la caña de azúcar, solo se encontró un modelo de optimización sobre el comportamiento de las emisiones de $\mathrm{N}_{2} \mathrm{O}$, lo que corrobora que desde el punto de vista de la DS, no existe mucha información sobre modelación del comportamiento de la HC en sistemas de cultivo de caña de azúcar.

Vale la pena mencionar, que ninguno de los trabajos revisados consideró la quema de desperdicios y combustibles fósiles usados en las industrias del sector agrícola. Particularmente, se encontró un estudio en el cultivo de la caña de azúcar, el cual solamente se enfocó en las emisiones de $\mathrm{N}_{2} \mathrm{O}$ generadas por la descomposición de los fertilizantes nitrogenados en los suelos gestionados. Sin embargo, a pesar de que la quema de desperdicios y combustibles fósiles no representa una fuente principal de emisiones, es valioso poner en consideración en futuros estudios, el comportamiento de las emisiones de $\mathrm{CO}_{2}$ aportadas por las actividades antropogénicas de este sector.

\section{Proyecto de investigación futuro}

Un futuro proyecto de investigación, que desarrollaran los autores, se concentrará en buscar la manera de diseñar un modelo de complejidad dinámica en el sector de la agricultura, específicamente en un sistema de cultivo de caña de azúcar en el departamento del Valle del Cauca, Colombia, con el fin de cubrir algunos de los vacíos investigativos descritos. En la primera etapa de dicho modelamiento se espera visualizar a las emisiones de $\mathrm{CO}_{2}$ y $\mathrm{N}_{2} \mathrm{O}$ generadas por las dos fuentes principales de emisión: combustibles fósiles y fertilizantes, propios de las labores de adecuación de la tierra y la preparación del suelo. Adicionalmente, como futuras etapas de este estudio se propone analizar el com- sider SD tools to overcome the mentioned challenge, and thus support organizations in making effective decisions.

As reviewed, SD models are useful for analyzing socio-economic impacts and cost-effective mitigation strategies that maintain production levels and soil fertility. Hence, this literature review focused on research studies in both the energy and agriculture sectors, which are responsible for generating most of the $\mathrm{CO}_{2}$ (transportation, production systems, services, residential sub-sectors), $\mathrm{CH}_{4}$ (livestock systems), and $\mathrm{N}_{2} \mathrm{O}$ (cropping systems) emissions.

Regarding the energy sector, this review presents some examples of studies on the environmental effects produced by the economic, transport, industrial, and integrated systems of cities; these were performed in Japan, China, the United States, and Brazil. On the other hand, in the agriculture sector, and specifically in livestock systems, some current whole-farm models were described, mainly of $\mathrm{CH}_{4}$ emissions as a result of solid wastes from animal farming, with applications in dairy farms in the developed countries. Likewise, for cropping systems, emissions behavior was analyzed in different kinds of tillage (conventional, reduced, and non-tillage), specifically for rice, wheat, maize, and sugarcane crops in tropical countries and China, the USA, and Australia. Concerning sugarcane, only one optimal model was found on $\mathrm{N}_{2} \mathrm{O}$ emission behavior. Indeed, from the point of view of SD, there is not much information about the modeling of $\mathrm{CF}$ behavior in sugarcane cropping systems.

Furthermore, none of the works reviewed in this paper took into account the burning of waste or fossil fuel use factors from the agriculture sector. In particular, in the sugarcane crop study, the focus was only on $\mathrm{N}_{2} \mathrm{O}$ emission generated by $\mathrm{N}$ fertilizers. Although the waste burning and fossil fuel use factors do not represent the main source of emissions, it is worth considering the dynamic behavior of $\mathrm{CO}_{2}$ emissions which are generated by anthropogenic activities in this sector.

\section{Future research project}

Above all, the reason why this study is proposed as a future research project (see Section 1) is to look for a way to design a complex dynamic model for the agriculture sector, and specifically for the sugarcane cropping system in the state of Valle del Cauca, Colombia. With the aim of covering some of the research gaps identified above, in the first stage of this modeling study it is hoped to visualize the $\mathrm{CO}_{2}$ and $\mathrm{N}_{2} \mathrm{O}$ emissions generated by 
two specific emission sources. These are the use of fossil fuel and fertilizer, arising from land suitability and soil preparation activities. Furthermore, as a future stage of this study it is proposed to analyze carbon emissions behavior as concerns the burning of agricultural waste executed at the end of the harvesting operation.

So, the proposed study will contribute significantly to the research line of the Icubo group within the Industrial Engineering Department of Universidad Icesi, known as Design and Management for Sustainability and Environment, by adding knowledge related to the behavior of GHG in field work on sugarcane crops from the state of Valle del Cauca. Overall, this will be a source of enrichment methodologies, tools, measurement models and CF behavioral analysis for the agro-industrial sector.

Finally, since it is necessary to have detailed statistics about GHG emissions generated by Colombian cropping systems, the proposed research project hopes to contribute to the National Greenhouse Gas Inventory specifically for Colombia, through a primary estimation of $\mathrm{CO}_{2}$ and $\mathrm{N}_{2} \mathrm{O}$ emissions behavior from the point of view of a sugarcane crop.

\section{Acknowledgments}

This research is funded by the Departamento Administrativo de Ciencia, Tecnología e Innovación (Colciencias) and its fóvenes Investigadores Program; also by Icubo, a research group of the Industrial Engineering Department of Universidad Icesi. \$s portamiento de las emisiones de carbono considerando la quema de desperdicios agrícolas que se presenta durante la preparación y cosecha del cultivo.El estudio propuesto contribuirá además, de manera significativa, a la línea de investigación «Diseño y manejo de la sostenibilidad» del grupo de investigación Icubo, del Departamento de Ingeniería Industrial de la Universidad Icesi, a través de su contribución al conocimiento respecto del comportamiento de los GEI en el campo de trabajo de un cultivo de caña de azúcar ubicado en la zona citada. Se espera que el estudio propuesto aporte al conocimiento como una fuente de metodologías, herramientas, modelos de medidas y análisis del comportamiento de la $\mathrm{HC}$ en el sector agroindustrial, con un pensamiento holístico y sistémico de la situación actual.

Por otro lado, dada la importancia de conocer estadísticas sobre los GEI generados por los sistemas de cultivo colombianos, el proyecto de investigación propuesto espera contribuir con estadísticas al inventario nacional de GEI, a través de una primera estimación del comportamiento de las emisiones de $\mathrm{CO}_{2}$ y $\mathrm{N}_{2} \mathrm{O}$ en un cultivo de caña de azúcar.

\section{Agradecimientos}

Esta investigación fue desarrollada con el apoyo del departamento administrativo de ciencia, tecnología e innovación (Colciencias) y su programa de jóvenes investigadores, en el grupo de investigación Icubo, perteneciente al Departamento de Ingeniería Industrial de la Universidad ICESI. SRT

\section{References / Referencias}

Aggarwal, P. K., Kalra, N., Chander, S., \& Pathak, H. (2005). InfoCrop: a dynamic simulation model for the assessment of crop yields, losses due to pests, and environmental impact of agro-ecosystems in tropical environments. I. Model description. Agricultural Systems, 89(1), 1-25.

Aggarwal, P.K, Kalra, N., Chander, S., \& Pathak, H. (2006). InfoCrop: A dynamic simulation model for the assessment of crop yields, losses due to pests, and environmental impact of agro-ecosystems in tropical environments. II. Performance of the model. Agricultural Systems, 89, 46-47.

Alkafoury, A., Bady, M., Aly, M. H. F., \& Negm, A. M. (2013). Emissions Modeling for Road Transportation in Urban Areas: State-of-Art Review. Proceeding of 23rd International Conference on Environmental Protection is a Must (Vol.23).

Asocaña. (s.f.). El Sector Azucarero Colombiano en la actualidad. from http://www.asocana.org/publico/info.aspx?Cid=215

Baumert, K. A., Herzog, T., \& Pershing, J. (2005). Navigating the numbers: Greenhouse gases and international climate change agreements. World Resources Institute

Brown, L., Scholefield, D., Jewkes, E., \& Lockyer, D. (2003). NGAUGE: a decision support system to optimise N fertilization of UK grassland for economic and/or environmental goals. Paper presented at the 12th N Workshop, Exeter, UK.

Chi, Y., Guo, Z., Zheng, Y., \& Zhang, X. (2014). Scenarios analysis of the energies' consumption and carbon emissions in China based on a dynamic CGE Model. Sustainability, 6(2), 487-512.

Del Grosso, S. J., Ojima, D. S., Parton, W. J., Stehfest, E., Heistemann, M., DeAngelo, B., \& Rose, S. (2009). Global scale DAYCENT model analysis of greenhouse gas emissions and mitigation strategies for cropped soils. Global and Planetary Change, 67(1), 44-50.

Del Grosso, S., Mosier, A., Parton, W., \& Ojima, D. (2005). DAYCENT model analysis of past and contemporary soil $\mathrm{N}<\mathrm{sub}>$ $2</$ sub $>0$ and net greenhouse gas flux for major crops in the USA. Soil and Tillage Research, 83(1), 9-24.

Del Prado, A., Scholefield, D., Chadwick, D., Misselbrook, T., Haygarth, P., Hopkins, A., . . Turner, M. (2006). A modelling framework to identify new integrated dairy production systems. Grassland Science in Europe, 11, 766-768. 
Denmead, O., Macdonald, B., Bryant, G., Naylor, T., Wilson, S., Griffith, D. W., . . Moody, P. (2010). Emissions of methane and nitrous oxide from Australian sugarcane soils. Agricultural and Forest Meteorology, 150(6), 748-756.

Dyner, I., Smith, R. A., \& Peña, G. E. (1995). System dynamics modelling for residential energy efficiency analysis and management. Journal of the Operational Research Society, 46(10), 1163-1173.

Feng, Y., Chen, S., \& Zhang, L. (2013). System dynamics modeling for urban energy consumption and co $<$ sub $>2</$ sub $>$ emissions: A case study of Beijing, China. Ecological Modelling, 252, 44-52.

Food, Agriculture Organization of the United Nations [FAO]. (2006). Fertilizer use by crop [FAO Fertilizer Plant Nutrition, Bulletin 17]. Rome. Italia: FAO.

Ford, A. (1983). Using simulation for policy evaluation in the electric utility industry. Simulation, 40(3), 85-92.

Giger-Reverdin, S., Morand-Fehr, P., \& Tran, G. (2003). Literature survey of the influence of dietary fat composition on methane production in dairy cattle. Livestock Production Science, 82(1), 73-79.

Gitay, H., Suárez, A., Watson, R., \& Dokken, T. J. [Eds.]. (2012). Cambio climático y biodiversidad. Ginebra, Suiza: Intergovernmental Panel on Climate Change.

Hediger, W. (2006). Modeling GHG emissions and carbon sequestration in Swiss agriculture: An integrated economic approach. Paper presented at the International Congress Series.

Hernández, N., Soto, F., \& Caballero, A. (2009). Modelos de simulación de cultivos: Características y usos. Cultivos Tropicales, 30(1), 73-82.

Horng, J.-J., Lee, R., \& Liao, K. (2004). Using STELLA system dynamicmodel to analyzegreenhouses gases/ emission from solid waste management in Taiwan (698466). Paper presented at the Symposia Papers Presented Before the Division of Environmental Chemistry American Chemical Society.

Houghton, J. T. (1997). Revised 1996 IPCC guidelines for national greenhouse gas inventories: Intergovernmental Panel on Climate Change.

IDEAM [Ed.]. (2009). Inventario nacional de gases de efecto invernadero, años 2000 y 2004. Bogotá, Colombia: IDEAM, MAVDT y PNUD.

ISEE Systems. (2006). Technical Document for the Ithink and STELLA Software.

Jones, J., Keating, B., \& Porter, C. (2001). Approaches to modular model development. Agricultural Systems, 70(2), 421-443.

Joumard, R., Andre, J.-M., Rapone, M., Zallinger, M., Kljun, N., Andre, M., . . . Weilenmann, M. (2007). Emission factor modelling and database for light vehicles-Artemis deliverable 3.

Keating, B. A., Carberry, P. S., Hammer, G. L., Probert, M. E., Robertson, M. J., Holzworth, D., . . Hochman, Z. (2003). An overview of APSIM, a model designed for farming systems simulation. European Journal of Agronomy, 18(3), 267-288.

Keating, B., Robertson, M., Muchow, R., \& Huth, N. (1999). Modelling sugarcane production systems I. Development and performance of the sugarcane module. Field Crops Research, 61(3), 253-271.

Klier, C. G., Haberbosch, S.,. Ruser, C., Stenger, R., Flessa, H., \& Priesack, E. (2011). Modeling nitrous oxide emissions from potato-cropped soil. Vadose Zone Journal, 10(1), 184-194. doi: 10.2136/vzj2009.0194

Lei, X., Zhang, J., \& Li, J. (2012). A system dynamics model for urban low-carbon transport and simulation in the city of Shanghai, China. AISS: Advances in Information Sciences and Service Sciences, 4(1), 239-246.

Li, H., Qiu, J., Wang, L., Tang, H., Li, C., \& Van Ranst, E. (2010). Modelling impacts of alternative farming management practices on greenhouse gas emissions from a winter wheat-maize rotation system in China. Agriculture, Ecosystems \&Environment, 135(1), 24-33.

Martínez, F. L., \& Londoño, J. E. (2013). El pensamiento sistémico como herramienta metodológica para la resolución de problemas. Revista Soluciones de Postgrado, 4(8), 43-65.

Matsumoto, K. (2011). Economic analysis of CO2 emission abatement applying a dynamic CGE model with endogenous technological change: Impacts of the time horizon (pp. 1454-1463). University of Shiga Prefecture.

Naill, R. F. (1992). A system dynamics model for national energy policy planning. System Dynamics Review, 8(1), 1-19.

Newell, J. P., \& Vos, R. O. (2011). "Papering" over space and place: product carbon footprint modeling in the global paper industry. Annals of the Association of American Geographers, 101(4), 730-741.

Olesen, J. E., Schelde, K., Weiske, A., Weisbjerg, M. R., Asman, W. A., \& Djurhuus, J. (2006). Modelling greenhouse gas emissions from European conventional and organic dairy farms. Agriculture, Ecosystems \& Environment, 112(2), 207-220.

Pannkuk, C., Stöckle, C., \& Papendick, R. (1998). Validation of CropSyst for winter and spring wheat under different tillage and residue management practices in a wheat-fallow region. Agric. Syst, 57, 121-134.

Penman, J. (2000). Good practice guidance and uncertainty management in national greenhouse gas inventories. Kanawaga, Japan: Institute for Global Environmental Strategies.

Peter, S., Hartmann, M. and Hediger, W. (2006). Modeling the structural adjustment process in Swiss agriculture to estimate future greenhouse gas and nitrogen emissions and evaluate policy options.96th EAAE Seminar: Institute of Agricultural Economics.

Probert, M., Dimes, J., Keating, B., Dalal, R., \& Strong, W. (1998). APSIM's water and nitrogen modules and simulation of the dynamics of water and nitrogen in fallow systems. Agricultural Systems, 56(1), 1-28.

Qudrat-Ullah, H. (2005). MDESRAP: a model for understanding the dynamics of electricity supply, resources and pollution. International Journal of Global Energy Issues, 23(1), 1-14. 
López, A., Rodríguez, L.M., Lubo, C., Arenas, F. \& Sierra, B. (2014).

Regmi, M.B. (2012). Climate Change and Transport: Assessment of Freight Modal Shift and Emissions through Dry Port Development. Saarbrücken, Alemania: Lap Lambert

Riedo, M., Grub, A., Rosset, M., \& Fuhrer, J. (1998). A pasture simulation model for dry matter production, and fluxes of carbon, nitrogen, water and energy. Ecological Modelling, 105(2), 141-183.

SAC. (2012). Sector Agroindustrial Colombiano. Bogotá: PROEXPORT COLOMBIA.

Schils, R., Olesen, J. E., Del Prado, A., \& Soussana, J. (2007). A review of farm level modelling approaches for mitigating greenhouse gas emissions from ruminant livestock systems. Livestock Science, 112(3), 240-251.

Senge, P. M. (1995). La quinta disciplina en la práctica: cómo construir una organización inteligente. Bogotá, Colombia: Norma.

Sterman, J. D. (2000). Business dynamics: systems thinking and modeling for a complex world (Vol. 19). Irwin/McGraw-Hill Boston.

Sterman, J. D. (2002). System Dynamics: systems thinking and modeling for a complex world. Paper presented at the Proceedings of the ESD Internal Symposium.

Stöckle, C., Higgins, S., Kemanian, A., Nelson, R., Huggins, D., Marcos, J., \& Collins, H. (2012). Carbon storage and nitrous oxide emissions of cropping systems in eastern Washington: A simulation study. Journal of Soil and Water Conservation, 67(5), 365-377.

Thorburn, P. J., Biggs, J. S., Collins, K., \& Probert, M. (2010). Using the APSIM model to estimate nitrous oxide emissions from diverse Australian sugarcane production systems. Agriculture, Ecosystems \&Environment, 136(3), 343-350.

Trappey, A. J., Trappey, C. V., Hsiao, C.-T., Ou, J. J., \& Chang, C.-T. (2012). System dynamics modelling of product carbon footprint life cycles for collaborative green supply chains. International Journal of Computer Integrated Manufacturing, 25(10), 934-945

Villarreal, D. (2011). Understanding GHG emissions: Stock vs. Flows. from http://blogs.ei.columbia.edu/2011/07/18/understanding-ghg-emissions-stock-vs-flows/

Wang, Z., Zhang, B., Li, X.-Y., Song, K.-S., Liu, D.-W., \& Zhang, S.-Q. (2006). Using CropSyst to simulate spring wheat growth in black soil zone of northeast China. Pedosphere, 16(3), 354-361.

Wang, H., \& McGlinchy, I. (2009). Review of vehicle emission modelling and the issues for New Zealand. Paper presented at the Proceedings of the 32nd Australasian Transport Research Forum.

Wang, M., Wu, M., Huo, H., \& Liu, J. (2008). Life-cycle energy use and greenhouse gas emission implications of Brazilian sugarcane ethanol simulated with the GREET model. International Sugar Journal, 110(1317).

Zhang, Z. X. (1998). Macroeconomic effects of $\mathrm{CO}<\mathrm{sub}>2</ \mathrm{sub}>$ emission limits: A computable general equilibrium analysis for China. Journal of Policy Modeling, 20(2), 213-250. 


\section{CURRICULUM VITAE}

Andrés López Astudillo Candidate to Doctor in Strategy and Organization from Universidad de Valencia (Spain). Master in Information and Knowledge's Society from Universidad Oberta de Cataluña (Barcelona, Spain). Specialist in Marketing, Specialist in Production Management, MBA and Business Administrator from Universidad Icesi (Cali, Colombia). Director of Specialization in Environmental Management at Universidad Icesi. His areas of professional interest include environmental management and topics related with carbon footprint, areas he has addressed from several research projects.

Lina Marcela Rodríguez Cum Laude Industrial Engineer from Universidad Icesi (Cali, Colombia). As part of Young Researchers initiative (Colciencias), she participates in the research group Icubo of the Universidad Icesi, in the project «Carbon Footprint Calculation of a Sugarcane Cultivation». In 2013, as a student, she was part of the research team of the project «Implementation of Value Stream Mapping in the process of product Storage and Dispatch without palletizing in candy plant Colombina», company where she developed her professional practice.

Claudia Marcela Lubo Industrial Engineer and Master in Industrial Engineering from Universidad Icesi (Cali, Colombia). As part of Young Researchers Project (Colciencias) she is member of the research group Icubo (Universidad Icesi), where she participates in the project «Carbon Footprint Calculation of a Sugarcane Cultivation».

Fernando Antonio Arenas Doctor (c) in Business Management and Strategy from Universidad de Valencia (Spain); Chemical Engineer and Master in Environmental Engineering from Universidad Nacional de Colombia (Bogotá). Post-graduate and pregraduate professor at Universidad Icesi (Cali, Colombia). Director or $\mathrm{i}^{3}$ research team, member of the System Dynamics Society and the European Academy of Management, and reviewer at the European Management Journal.

Beatriz Eugenia Sierra Biologist from Universidad del Valle (Cali, Colombia) and Specialist in Environmental Management from Universidad Icesi (Cali). Currently she is a professor in the areas of Design for the Environment and Degree Projects at the Department of Industrial Engineering (Universidad Icesi). She is part of the researchers team of the «Calculation of Carbon Footprint in a Sugarcane Growing» project. 